Canadian

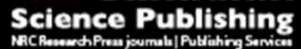

Canadian Journal of Forest Research Revue canadienne de recherche forestière

\title{
Relationships of wood anatomy with growth and wood density in three Norway spruce clones of Finnish origin
}

\begin{tabular}{|c|c|}
\hline Journal: & Canadian Journal of Forest Research \\
\hline Manuscript ID & cjfr-2017-0025.R3 \\
\hline Manuscript Type: & Article \\
\hline Date Submitted by the Author: & 07-Jun-2017 \\
\hline Complete List of Authors: & $\begin{array}{l}\text { Luostarinen, Katri; University of Eastern Finland, Faculty of Science and } \\
\text { Forestry } \\
\text { Pikkarainen, Laura; University of Eastern Finland, Faculty of Science and } \\
\text { Forestry } \\
\text { Ikonen, Veli-Pekka; UEF, University of Eastern Finland, Faculty of Science } \\
\text { and Forestry, School of Forest Sciences } \\
\text { Zubizarreta-Gerendiain, Ane; University of Eastern Finland, School of } \\
\text { Forest Science } \\
\text { Pulkkinen, Pertti; Natural Resources Institute Finland Haapastensyrjä } \\
\text { Breeding Station, FI-16200, } \\
\text { Peltola, Heli; University of Eastern Finland, School of Forest Sciences }\end{array}$ \\
\hline Keyword: & Picea abies, xylem, tracheid, resin canal, ray \\
\hline $\begin{array}{r}\text { Is the invited manuscript for } \\
\text { consideration in a Special } \\
\text { Issue? : }\end{array}$ & N/A \\
\hline
\end{tabular}


1 Relationships of wood anatomy with growth and wood density in three Norway spruce clones 2 of Finnish origin

3

4 Katri Luostarinen ${ }^{1)^{*}}$, Laura Pikkarainen ${ }^{1)}$, Veli-Pekka Ikonen ${ }^{1)}$, Ane Zubizarreta 5 Gerendiain $^{1)}$, Pertti Pulkkinen ${ }^{2)}$, Heli Peltola ${ }^{1)}$

6

$7 \quad{ }^{1)}$ University of Eastern Finland, Faculty of Science and Forestry, School of Forest Sciences, P.O.

8 Box 111, FI-80101 Joensuu, Finland. Katri Luostarinen (katri.luostarinen@uef.fi), Laura 9 Pikkarainen (pikkarainen.laura@gmail.com), Veli-Pekka Ikonen (veli-pekka.ikonen@uef.fi), 10 Ane Zubizarreta Gerendiain (ane.zubizarreta@uef.fi), Heli Peltola (heli.peltola@uef.fi)

11

$12^{2)}$ Natural Resources Institute Finland, Haapastensyrjä Station, FI-16200 Läyliäinen, Finland. Pertti 13 Pulkkinen (pertti.pulkkinen@luke.fi)

14

15 *Corresponding author: Katri Luostarinen, tel +358 50442 2924, katri.luostarinen@uef.fi

16 
18

19

34 Keywords: Picea abies, xylem, tracheid, resin canal, ray

\section{Abstract}

The relationships between anatomical characteristics of wood, growth, and wood density were studied in three Finnish Norway spruce clones, which had differences in average stem volume and wood density. This was done to determine which anatomical characteristics are affected by growth and which affect wood density, and to determine if clones of different geographical origins (Southeastern, C43; Southern, C308; Southwestern, C332) differ from each other in these respects. In this study, tracheid double wall thickness (2CWT), lumen diameter and wall:lumen ratio, numbers, sizes, and percentages of resin canals, and numbers of rays were correlated with ring, earlywood, and latewood widths and densities. The wood density correlated positively with the wall:lumen diameter ratio. Rapid growth decreased the number of rays independently of the clone. Furthermore, the effects of growth on the number and size of resin canals depended strongly on the clone. C332 had very thin tracheid walls in latewood, which decreased wood density. However, the high number of rays and resin canals increased it. Growth significantly influences wood anatomy and, consequently, wood density. Hence, wood anatomy should be considered in the selection of proper genotypes for forest cultivation in a changing, growing environment. 


\section{Introduction}

In Nordic forested countries like Finland, Norway spruce (Picea abies (L.) Karst.) is an important raw material for a forest-based bioeconomy (Finnish Statistical Yearbook of Forestry 2014). To fulfill the increasing raw material needs of different wood-using industries in the long run, breeding and cultivation of genotypes with desired properties should be promoted in increasing amounts. However, this would require deep understanding of the relationships between growth and wood properties in different genotypes. In Nordic countries, the primary basis for the selection of tree genotypes for breeding has been volume growth, and less attention has been paid to the relationships between growth and other properties affecting wood density, despite the importance of density in many wood products (Karlsson and Rosvall 1993; Skog et al. 2014). The relationship between growth and wood density is complex and varies between genotypes. It is usually negative (Zobel and Jett 1995), but nonsignificant (Zubizarreta Gerendiain et al. 2007) or weak positive relationships have also been found in some Norway spruce clones (Bujold et al. 1996; Zubizarreta Gerendiain et al. 2007). As one property may affect other properties, the most important ones (e.g. growth and wood density traits) should be considered simultaneously in tree breeding.

The desired properties of wood depend largely on the end use requirements of wood. For example, a high wood density means commonly good mechanical wood properties (Fischer et al. 2016). In addition, the higher the wood density, the higher the yield of wood compounds per volume unit of wood. For pulp, a high proportion of cellulose, located in tracheids, is desired (Sjöström 1993), whereas for extractives, the proportion of parenchyma cells is important, as these cells store nutrients that can be turned into extractives. Some extractives have useful properties for health, for example (Willför et al. 2003), while some others may be toxic (Uprichard 1993). In structural use, extractives commonly increase the durability of wood against decay (Uprichard 1993), and, on the other hand, they may increase the need for cleaning saw blades, for example, as they stick on them during machining (Bergstedt and Lyck 2007), or they may hinder the finishing of wood (Uprichard 
1993). Instead, for example, in outdoor nonsupporting structures, a lower wood density is good because lighter structures are easier to fix and they require lighter support. In addition, wood of low density swells and shrinks less with varying relative air humidity, and thus, cracks less during usage (Kärkkäinen 2007), providing fewer ways for microbes to infect the wood. Solid Norway spruce wood best suits nonsupporting structures, products made of veneers using hot-pressing (structural plywood, laminated veneer lumber), and cellulose and its derivatives (Sjöström 1993; Kärkkäinen 2007).

Wood density is mainly affected by the ratio between tracheid wall thickness and lumen size (de Kort et al. 1991; Mitchell and Denne 1997; Hannrup et al. 2001). Wood possessing thicker tracheid walls is denser than that with thinner walls, assuming that the lumen size is the same. As the walls of latewood (LW) tracheids are thicker with usually quite small lumens compared to earlywood (EW), the proportions of these wood types markedly affect the overall wood density (Luostarinen 2011). According to Zubizarreta Gerendiain et al. (2007), a higher growth rate increases the width of EW, while the amount of LW remains relatively constant in Norway spruce. The effects of cell types in xylem other than tracheids on wood density have clearly been less studied. Spruce wood also contains parenchyma cells (ray cells, epithelial cells of resin canals), of which at least the rays are quite dense (Hoffmann and Timell 1972). In addition, resin produced by epithelial cells of resin canals increases the density of solid wood (Barger and Ffolliott 1971; Rissanen and Sipi 2002). The number of particularly traumatic resin canals may be high as their formation is induced by stresses (Wimmer and Grabner 1997). Thus, the role of parenchyma cells in overall wood density may be important, but it is still poorly known.

In the study by Zubizarreta Gerendiain et al. (2007), some Finnish Norway spruce clones had both higher stem volume and wood density than average (e.g. C43). Some other clones had both quite average stem volume and wood density (e.g. C308), and some had relatively low stem volume but 
average wood density (e.g. C332). In this study, we investigated the relationships of anatomical characteristics with growth and wood density factors in these three clones of different geographical origins. This was done to determine which anatomical characteristics are affected by growth and which characteristics affect wood density, and to determine whether clones differ from each other in these respects. In particular, we investigate the effects of tracheid wall:lumen ratio, the number and the size of rays and resin canals on the wood density variation. The hypotheses are that rays and resin canals increase the wood density of Norway spruce, because they both consist of mainly parenchyma cells with high density, and, in addition, epithelial parenchyma of resin canals produce resin, which fills the empty spaces of wood. Furthermore, the formation of resin canals is partly caused by unfavorable growth conditions, which may affect wood density through channeling resources to resin canals instead of tracheids.

\section{Materials and methods}

\section{Experimental data and X-ray densitometry measurements}

In this work, we use Zubizarreta Gerendiain et al.'s (2007) X-ray microdensitometry data of three Norway spruce clones - C43 (N=8 trees, geographical origin: Southeastern Finland, Miehikkälä), C308 (N=9 trees, Southern Finland, Loppi), and C332 (N=10 trees, Southwestern Finland, Pöytyä). The sample trees of clones were originally harvested in spring 2004 from the Norway spruce clone trial established in 1974 in Imatra, in Southeastern Finland $\left(28^{\circ} 48^{\prime} \mathrm{E}, 61^{\circ} 08^{\prime} \mathrm{N}, 60 \mathrm{~m}\right.$ a.s.1., 1300 degree-days), on mineral agricultural soil with site fertility typical for the cultivation of Norway spruce. At the time of harvesting, their height and stem diameters were measured (Table 1) and sample discs were cut at a height of $1 \mathrm{~m}$ for further analyses of intra-ring growth and wood properties. Small wood samples (a radial segment of $5 \mathrm{~mm}$ x $5 \mathrm{~mm}$ ) were cut from each disc from pith to bark and then conditioned to $12 \%$ equilibrium moisture content before X-ray measurements. 
112 For each tree, the data include average ring width (RW, mm), EW and LW widths (EWW and

113 LWW, respectively, mm), mean wood density $\left(\mathrm{RD}, \mathrm{g} / \mathrm{cm}^{3}\right)$, and EW and LW densities (EWD and

114 LWD, respectively, $\mathrm{g} / \mathrm{cm}^{3}$ ) measured for each sample tree. They were determined by employing the

115 ITRAX X-ray microdensitometer (Fig. 1a, b, Table 1). The resolution of the ITRAX measurements

116 was 40 measurements per mm, and the X-ray intensity was $30 \mathrm{kV}$ and $35 \mathrm{~mA}$ with exposure time of

11720 ms. X-ray radiographic images were further analyzed by the Density Profile Analyzer Package,

118 and the resulting intra-ring density profiles were used to determine different ring variables using

119 Excel macros. The means of the maximum and minimum intra-ring densities were used as

120 thresholds for EWW ( $<$ mean) and LWW ( $>$ mean) in each ring.

121

122

123

124

125

126

127

128

129

130

131

132

133

134

135

136

\section{Measurements of anatomical characteristics}

The wood specimens used for ITRAX measurements were cut into shorter pieces for anatomical measurements. This was done because a whole strip was too long to be cut with a microtome and to be mounted on a slide. Before sectioning, the wood was also softened in boiling water for 30-45 min, after which it was allowed to cool down. Cross sections, $20 \mu \mathrm{m}$ thick, were cut using a rotary microtome (Microm). The sections were stained with safranin-alcian blue (Fagerstedt et al. 1996), after which they were mounted with DePex.

Anatomical measurements were carried out using a Leica stereomicroscope and a Leitz Laborlux 12 light microscope with a Micropublisher 5.0 camera and Image Pro 7.0 software. With the Leica microscope, the number of rays was counted tangentially from each annual ring from the middle of the ring from a width of $3.3 \mathrm{~mm}$. In addition, the number of resin canals was counted for each ring from the same figures, separately for EW and LW, from a tangential width of $3.3 \mathrm{~mm}$. The radial widths measured for EW and LW using an ITRAX X-ray microdensitometer were applied in microscopy as well, to differentiate between these wood types. Resin canals were classified as 
137

138

139

140

141

142

143

144

145

146

147

148

149

150

151

152

153

154

155

156

157

158

159

160

normal or traumatic (see e.g. Wimmer and Grabner 1997). The number of rays and resin canals is presented per $\mathrm{mm}^{2}$ using the area of the particular ring as the divider.

Using the Leitz microscope, we measured the thickness of the double tracheid cell wall (2CWT) and tracheid lumen diameter in the radial direction from four cells from the middle of both EW and LW. These measurements were carried out for each annual ring from the pith to the bark. In addition, the diameter of two resin canals was measured both tangentially and radially. Two resin canals from both EW and LW were measured when possible. In some rings, there was only one canal in the studied section, and in some rings they were totally missing from the monitored sector.

From both tangential sides of the measured resin canals, the radial thickness of one $2 \mathrm{CWT}$ of the nearest tracheids was measured.

\section{Data analyses}

The tracheid wall:lumen ratio was calculated as the 2CWT:radial lumen diameter. The average area of a resin canal was calculated assuming that the radius of a canal is half of the average tangential and radial diameter and that the canals are circles. The average percentage area of resin canals in a ring was calculated by multiplying the average area of canals by their number and relating the area of canals to the area of the monitored sector of each ring (3.3 $\mathrm{mm} \times$ ring width $\mathrm{mm})$.

The coefficient of variation was calculated for the measured variables to compare their deviations within a clone as follows:

$$
C V(\%)=\frac{S D}{X} \times 100
$$

where $\mathrm{CV}(\%)=$ coefficient of variation, $\mathrm{SD}=$ standard deviation, and $\mathrm{X}=$ mean of a clone. 
163 The means of each variable were compared between clones using the general linear model (GLM)

164 multivariate analysis of variance (SPSS 21). Standard deviation shows that there is some variation

165 within clones, but such variation was not studied in this work. Instead, we were interested in the

166 differences between clones. Pairwise comparisons were carried out using the parametric Tukey test

167 when possible; otherwise, the nonparametric Tamhane test was used. Differences between clones

168 were considered statistically significant at $p<0.05$. Phenotypic correlations between anatomical

169 characteristics and wood density and tree growth properties, were calculated using the Pearson

170 correlation procedure. The correlations exhibiting $\mathrm{p}<0.05$ were considered significant.

171

172

173

174

175

176

177

178

179

180

181

182

183

184

185

186

187

188

\section{Results}

\section{Variation of anatomical characteristics between clones}

The 2CWTs of EW and LW tracheids differed between clones (Table 2, Fig. 2a). In EW, the 2CWT increased slightly from the pith to the bark regardless of clone, but it was lowest in C332. In LW, the increase in 2CWT was clear in C43 and C308, while in C332, the 2CWT of LW even slightly decreased after the $15^{\text {th }}$ annual ring down to the same level as the $2 \mathrm{CWT}$ of EW. The trends in 2CWT in LW between C43 and C308 were quite similar from the pith to the bark, i.e. peaks and lows occurred simultaneously. With regard to both EW and LW, the average $2 \mathrm{CWT}$ was lowest in C332 and highest in C43. The variation (CV\%) was lowest in C332.

The lumen diameter of EW tracheids was larger than that of LW tracheids. In C332, the EW lumens were the smallest and LW lumens the largest of all clones with the smallest variation (CV\%) (Table 2, Fig. 2b). In EW, the lumen diameter increased in a similar way regardless of clone. Instead, in LW, it slightly decreased from pith to bark in C43 and C308, but not in C332.

The ratio between $2 \mathrm{CWT}$ and lumen diameter was clearly higher in LW than in EW in all clones. In LW, the ratio was highest in C43 and smallest in C332 (Table 2, Fig. 2c). In LW, the ratio increased 
189

190

191

192

193

194

195

196

197

198

199

200

201

202

203

204

205

206

207

208

209

210

211

212

213

214

from the pith to the bark in the clones C43 and C308. However, it decreased slightly towards the bark in C332. In EW, the ratio was similar from the pith to the bark in all three clones. The variation (CV\%) was lowest in C332.

The 2CWT of the tracheids located beside the resin canals was slightly higher than $4 \mu \mathrm{m}$ in LW, and slightly smaller than $4 \mu \mathrm{m}$ in EW, in all clones (Table 2, Fig. 2d). The 2CWTs beside the resin canals of $\mathrm{C} 332$ were thinnest with lowest variation $(\mathrm{CV} \%)$ and differed significantly from the other clones. The 2CWT of tracheids located beside the resin canals did not differ between normal and traumatic resin canals within a clone or in EW and LW.

Deviation $(\mathrm{CV} \%)$ in the number of resin canals was large, and thus no significant differences between clones were observed, except in LW, in which C332 contained more resin canals than the other studied clones (Table 2, Fig. 3a). Furthermore, LW contained more resin canals per $\mathrm{mm}^{2}$ than EW, particularly at cambial ages higher than 8-13 years, depending on the clone. The percentage of the traumatic resin canals did not differ significantly between the clones.

The average area of a resin canal, both in the case of normal and traumatic ones, was smallest in C332 even though the area of individual canals varied greatly (Table 2, Fig. 3b). No trend from the pith to the bark was observed.

A large variation was also observed in the percentage area of resin canals between rings within the same clone and between clones. For the three clones, the peaks and lows occurred during the same growing season. Rings of the same cambial age of different clones do not necessarily represent the same calendar year. For example, the peak of 17 in C332, 18 in C308, and 19 years of cambial age in C43 present the same growing season (Table 2, Fig. 3c). The maximum area of resin canals in an annual ring was $2.5 \%$. 
216 The number of rays per $\mathrm{mm}^{2}$ differed between clones even though the within-clone deviation was

217 large in all the studied clones. It was highest, almost $140 \%$ of the average of the clones in C332, and 218 lowest, approximately $73 \%$, in C308. The number slightly decreased from the pith to 7-9 years of 219 cambial age, after which it increased slightly in C43 and C308 up to 22-23 years of cambial age. In 220 C332, the increase starting from ring 8 was clear (Table 2, Fig. 3d).

\section{Effects of growth properties on wood anatomy}

According to the calculated correlations, when the growth was faster, the tracheid walls were thinner, the lumens in EW were smaller, and the lumens in LW were larger in most cases (Table 3). Furthermore, fast growth decreased the wall:lumen ratio in LW in C43 and C308 but not in C332. The observed significant correlations between the studied anatomical characteristics and EWW, LWW, and RW were commonly similar, i.e. either positive or negative, in all three clones, if there were any. Exceptions were the correlation of the wall:lumen ratio of LW with LWW, and the LW lumen diameter with LWW. The former was positive in C332 and negative in two other clones, and in the case of the latter, the correlations were the opposite. However, in several cases, a significant correlation was missing from C332 while it occurred in the other studied clones.

The number of resin canals in EW, their area in EW, their total area as well as the ray number was correlated with radial growth (Table 3). The faster the radial growth, the more resin canals there were, especially in EW in C308. In LW, a significant negative correlation was observed only in C308 between the number of resin canals and LWW. When the growth was faster, the canals were larger, according to their average area particularly in EW in all three clones. On the other hand, the

238 percentage area of resin canals in EW, LW, or whole ring was usually the smaller, the faster the radial growth was. As regards C332, the percentage area of resin canals in LW did not correlate 
241 number of rays per $\mathrm{mm}^{2}$ was lower with faster the growth rates in all three clones and in both EW 242 and LW (Table 3).

\section{Effects of anatomical characteristics on wood density}

245 There were several significant correlations between wood density and measured anatomical 246 characteristics (Table 4). They were partly different regarding EW, LW, and whole ring. 247 Differences between clones existed as well.

The properties that correlated strongly with EWD in all clones were the tracheid lumen diameter in 250 EW and the number of resin canals in EW (Table 4). The larger the lumen diameter, the lower the 251 EWD, while in terms of the number of resin canals, the correlation was the opposite. The 2CWT in $252 \mathrm{LW}$, the lumen diameter in LW, and the average area of a resin canal in EW correlated negatively 253 with EWD in two clones, while the wall:lumen ratio in EW, the percentage area of resin canals in 254 EW, and the number of rays correlated positively with EWD in two clones, one of them being C332 255 in all cases. The 2CWT in EW (C43), the wall:lumen ratio in LW (C43), the average area of a resin 256 canal in LW (C332), and the percentage area of resin canals in LW (C332) correlated negatively, 257 and the percentage area of resin canals in a whole ring (C43) positively, with EWD only in one 258 clone.

The properties that strongly increased LWD in all clones were the high $2 \mathrm{CWT}$ in LW and 261 wall:lumen ratio in LW, while the large lumen diameter in LW decreased LWD (Table 4). In the 262 case of the large lumen diameter in EW and the high average area of a resin canal in EW, they 263 decreased the LWD in C332 and increased it in C43. In addition, the high 2CWT of EW strongly 264 increased the LWD in C43 and C308. Several resin canal properties correlated with LWD in C308 265 alone, increasing LWD except for the number in EW. The high number of rays increased LWD in $266 \quad \mathrm{C} 43$ and $\mathrm{C} 308$ but not in C332. 
RD was increased by the high wall:lumen ratios of both EW and LW and the high number of rays in

all three clones (Table 4). Instead, the high diameters of both EW and LW tracheid lumens

decreased RD, but the high 2CWT increased it only in EW in C308 and in LW in C43. The 2CWT beside the resin canals in $\mathrm{EW}$ did not affect $\mathrm{RD}$ in $\mathrm{C} 332$, while in two other clones the correlation was positive. The number of resin canals in EW increased RD of both $\mathrm{C} 43$ and C332, while the average area of a resin canal in both EW and LW decreased it in C332. The total area of resin canals in a whole ring increased RD of C43 and C308. Some opposite correlations that were observed regarding EW and LW overrode each other with regard to RD. This was the case with the 2CWT in EW in C43, the 2CWT in LW in C332, and the number of resin canals in EW in C308.

\section{Discussion}

In this study, growth affected wood density through wood anatomy in the three studied Finnish Norway spruce clones. As expected, important factors for wood density were the 2CWT and wall:lumen ratio, which were, commonly but not always, the larger the slower the growth was, resulting in denser wood. The correlations between wood density and 2CWT and wall:lumen ratio, 283 were weakest or missing in some cases, mostly in C332, which had average wood density but low growth. This clone possessed an atypical structure in annual rings, with LW being very similar to EW with exceptionally thin tracheid walls. It also had low $\mathrm{CV} \%$, indicating quite uniform wood. In addition to the narrowest rings and EW, the tracheids of $\mathrm{C} 332$ were the shortest of these three clones based on a previous study of Zubizarreta Gerendiain et al. (2008). Thus, the poorest wood and cell structure with regard to water transport may have caused there to be a larger need for water transportation in LW in C332 and thus, the tracheids of LW may have atypically large lumens and 290 thin walls. On the other hand, the typical structure in annual rings was observed in C43 and C308. 291 This means that the 2CWT of EW is clearly smaller than that of LW, and an increase in the 2CWT 292 in LW from the pith to the bark occurs. This has been observed in previous studies as well (e.g. 
293 Mäkinen et al. 2002a; Irbe et al. 2015). In this study the effects of tracheid anatomy on wood

294 density were also in line with the studies by de Kort et al. (1991), Mitchell and Denne (1997),

295 Hannrup et al. (2001), and Mäkinen et al. (2002b), i.e. thick walls and small lumens increased wood 296 density. As the LW tracheids of C332 had a small 2CWT and large lumen diameter, it resulted in an 297 exceptionally low wall:lumen ratio. However, this result did not correspond to the previous wood 298 density measurements of Zubizarreta Gerendiain et al. (2007), according to which the LWD of C332 and C308 is the same (see Table 1). The LWD of C332 should be clearly lower than that of C308 on the basis of the measured tracheid structure.

Numbers, sizes, and percentage areas of resin canals were variable and they did not have clear radial trends like the other studied anatomical characteristics. Furthermore, the effects of growth on the resin canal number and size were different between clones. Also, in a previous study by Wimmer and Grabner (1997), the canal number and size correlated variably with growth in Norway spruce. One reason for the variable relationships may be the different geographical origin of genotypes; thiseffect has been observed earlier as well (O'Neill et al. 2002; Hannrup et al. 2004;

Cown et al. 2011). In addition, stresses such as high summer temperature and water stress, as well as insect attacks or mechanical damage of trees, affect the number of resin canals and resin formation (Reid and Watson 1966; Wimmer and Grabner 1997; O’Neill et al. 2002; Cown et al.

311 2011) rather than the radial location of wood. This dependence of resin canals on the annual 312 growing conditions was also observed in this study.

314 In addition to even daily-changing weather factors, macroclimate factors such as air humidity 315 caused by the closeness of the coast may affect phenotype responses. For example, in Picea 316 sitchensis $\mathrm{x}$ P. glauca increasing distance from the Pacific Ocean has been observed to increase the 317 number of resin canals (O’Neill et al. 2002). In this study, C332 came from Pöytyä, Southwestern 318 Finland, which has humid sea winds, while the other clones came from more continental areas. The 
319 experimental site in Imatra is located farther from the sea than any of the original provenances and 320 has a continental climate. The transfer of C332 from a maritime to a continental climate may have 321 affected the formation of resin canals. Thus, it is possible that Norway spruce, or some genotypes of 322 it, are extremely sensitive to the climate of the growing site, causing atypical growth.

324 Even though the 2CWTs of tracheids beside the resin canals in LW were thin when compared to the 325 2CWTs of other tracheids within the same wood type, no proof of the decreasing effect of these 326 2CWTs on wood density was found. The significant positive correlation between the LWD and 327 2CWT of these tracheids in C43 but not in the other clones was due to the fact that the 2CWT of 328 these tracheids slightly increased towards the bark only in C43. However, thin walls beside the resin 329 canals suggest that allocating to the canals and resin seems to decrease local allocation of resources 330 to tracheid wall thickening. The possible decreasing effect of resin canals on wood density through 331 this mechanism would be higher if the wood contained more resin canals, while increasing the 332 concentration of resin would possibly increase the density at the same time (e.g. Barger and 333 Ffolliott 1971), particularly in Norway spruce with quite low wood density as such. Furthermore, 334 according to the observed correlations, a high number of resin canals in EW increased EWD in all 335 clones but decreased LWD in C308. This may mean that allocating to resin canals and resin in early 336 summer may decrease the allocation to LW later in the summer. In C332 and C43, a high number of 337 resin canals in EW increased RD. This is most likely due to the significant effect of resin on density 338 (e.g. Barger and Ffolliott 1971), particularly as resin is translocated into tracheids (Lloyd 1978). 339 Particularly in C332, the low 2CWT together with highest number of canals with a small area of 340 individual ones and their small percentage area emphasized the effect of resin. In contrast to this 341 study, Hannrup et al. (2004) found that the resin canal density (number/area) did not affect wood 342 density in spruce. Furthermore, epithelial cells that produce resin are parenchymatous (high lignin 343 concentration in walls, lumens not empty) and thus as such, may increase wood density (Hoffman 344 and Timell 1972; Chafe 1974). Based on the results of this study, the earlier measured quite high 
345 wood density values of C332 (Zubizarreta Gerendiain et al. 2007) may be partly caused by resin

346 canals because of the parenchymatous nature of the epithelial cells and/or their product, resin. In

347 practice, the role of resin canals for wood density may be contradictory and difficult to determine

348 because of their effect on 2CWT of tracheids located beside them in addition to resin and 349 parenchymatous nature of the cells.

351 In this study, fast growth decreased the number of rays, and a high number of rays increased the 352 wood density based on the observed correlations, even though some differences were observed 353 between clones. The number of rays was highest in C332. Thus the high number of rays may at 354 least partly explain the unexpectedly high wood density in C332 (Zubizarreta Gerendiain et al. 355 2007). The positive effect of rays on wood density is due to the high lignin concentration of the 356 walls, including the middle lamella, of ray parenchyma (Hoffman and Timell 1972; Chafe 1974; 357 Hori and Sugiyama 2003; Tokareva et al. 2007). As the walls of the ray cells are thin, the 358 proportion of middle lamella and lignin is higher in them than in tracheids, and their lumens are small and not empty. These factors make the density of rays quite high. Thus, a high number of rays might partly explain the high LWD in C332, despite the thin-walled tracheids. The positive effect of the number of rays on wood density has been observed in beech as well (Gryc et al. 2008). As in the case of parenchyma cells generally, including cells of resin canals, stress may increase the number of rays through increased concentration of the stress hormone ethylene (Barker 1979). However, genotype differences in their amounts are also possible.

\section{Conclusions}

367 Our results show that growth affects wood anatomy in Norway spruce, and the overall density of 368 Norway spruce wood is affected by all cell types of wood. The effects of rays and resin canals on 369 Norway spruce wood density have not been studied equally with tracheids in previous studies as far 370 as we know. Thus, the role of different cell types in wood density should be studied in more detail. 
372 The cell structure of wood should be considered in the selection of proper genotypes for cultivation 373 under changing environmental conditions, especially if higher wood density is desired 374 simultaneously with higher growth. This is because resin canals and rays may compensate for the 375 wood density loss caused by thin tracheid walls together with relatively large lumen. This was 376 observed in LW of the clone C332 in this study. An increase in wood density due to parenchyma 377 cells and their products is not normally desirable in structural timber, as their improving effect on 378 strength is weaker than that of tracheid walls. In addition, parenchyma does not increase the 379 cellulose yield, but affects extractive concentration of wood.

381 In addition, it should be noted that provenance transfer of genotypes even short distances might 382 affect the wood anatomy, particularly if the climate differs from that of the geographical origin. 383 However, the sensitivity of different genotypes to changes in the environment may vary. If wood 384 anatomy and, thus, wood properties can be affected by selection and/or transferring of a genotype, 385 these relationships should be studied more. When considering the economic profitability of wood 386 production and further use of wood for different purposes, specialized breeding for desired 387 properties should be promoted.

\section{Acknowledgements}

Mr. Raimo Jaatinen, Natural Resources Institute of Finland (formerly METLA) is thanked for measuring the sample trees and supplying wood discs for this study. Mrs. Maini Mononen, UEF, School of Forest Sciences, is thanked for preparation of anatomical crosscuts, and Mr. Jarmo

393 Pennala, UEF, School of Forest Sciences, is thanked for conducting X-ray analyses of wood specimens and measuring anatomical characteristics. 


\section{References}

Barger, R.L., and Ffolliot, P.F. 1971. Effects of extractives on specific gravity of southwestern ponderosa pine. USDA For. Serv. Res. Note RM-205.

Barker, J. E. 1979. Growth and wood properties of Pinus radiata in relation to applied ethylene. N. Z. J. For. Sci. 9(1): 15-19.

Bergstedt, A. and Lyck, C. 2007. Larch wood - a literature review. Forest and Landscape Papers 23/2007. Faculty of Life Sciences, University of Copenhagen. 66 p.

Bujold, S.J., Simpson, J.D., Beukeveld, J.H.J., and Schneider, M.H. 1996. Relative density and growth of eleven Norway spruce provenances in central New Brunswick. North. J. Appl. For. 13(3): 124-128.

Chafe, S.C. 1974. Cell wall structure in the xylem parenchyma of Cryptomeria. Protoplasma 81: 63.

Cown, D.J., Donaldson, L.A., and Downes, G.M. 2011. A review of resin features in radiata pine.

411 Fagerstedt, K., Pellinen, K., Saranpää, P., and Timonen, T. 1996. Mikä puu - mistä puusta. $412 \quad$ Yliopistopaino. Helsinki. 180 p.

413 Finnish Statistical Year Book of Forestry. 2014. Finnish Forest Resources Institute. Helsinki. 414 Vammalan Kirjapaino Oy. ISBN 9789514024504.

415 Fischer, C., Vestol, G., and Hoibo, O. 2016. Modelling the variability of density and bending 416 properties of Norway spruce structural timber. Can. J. For. Res. 46: 978-985. 417 dx.doi.org/10.1139/cjfr-2016-0022

418 Gryc, V., Vavrcik, H., Rybnicek, M., and Premyslovska, E. 2008. The relation between the 419 microscopic structure and the wood density of European beech (Fagus sylvatica). J. For. Sci. $420 \quad 54(4): 170-175$.

421 Hannrup, B., Cahalan, C., Chantre, G., Grabner, M., Karlsson, B., Le Bayon, I., Lloyd Jones, G., 422 Muller, U., Pereira, H., Rodrigues J.C., Rosner, S., Rozenberg, P., Wilhelmsson, L., and 
423

424

425

426

427

428

429

430

431

432

433

434

435

436

437

438

439

440

441

442

443

444

445

446

447

448

Wimmer, R. 2004. Genetic parameters of growth and wood quality traits in Picea abies. Scand.

$$
\text { J. For. Res. 19: 14-29. }
$$

Hannrup, B., Danell, Ö., Ekberg, I., and Moell, M. 2001. Relationships between wood density and tracheid dimensions in Pinus sylvestris L. Wood Fiber Sci. 33: 173-181.

Hoffman, G.C., and Timell, T.E. 1972. Polysaccharides in ray cells of normal wood of red pine (Pinus resinosa). Tappi 55(5): 733-736.

Hori, R., and Sugiyama, J. 2002. A combined FT-IR microscopy and principal component analysis on softwood cell walls. Carboh. Polym. 52: 449-453.

Irbe, I., Sable, I., Noldt, G., Grinfelds, U., Jansons, A., Treimanis, A., and Koch, G. 2015. Wood and tracheid properties of Norway spruce (Picea abies [L.] Karst.) clones grown on former agricultural land in Latvia. Baltic Forestry 21(1): 114-123.

Karlson, B., and Rosvall, O. 1993. Breeding programs in Sweden - Norway spruce. In: Lee, S.J. (Ed.). Proceedings of Progeny Testing and Breeding Strategies. Meeting of the Nordic Group for Tree Breeding, Edinburgh, 6-10 October 1993.

de Kort, I., Loeffen, V., and Baas, P. 1991. Ring width, density and wood anatomy of Douglas fir with different crown vitality. IAWA Bulletin ns. 12: 453-465.

Kärkkäinen, M. 2007. Puun rakenne ja ominaisuudet. Metsäkustannus, Hämeenlinna. 468 p.

Lloyd, J.A. 1978. Distribution of extractives in Pinus radiata earlywood and latewood. N. Z. J. For.

Sci. 8: 288-294.

Luostarinen, K. 2011. Density, annual growth and proportions of types of wood of planted fast grown Siberian larch (Larix sibirica) trees. Baltic Forestry 17: 58-67.

Mitchell, M.D., and Denne, M.P. 1997. Variation in density of Picea sitchensis in relation to within-tree trends in tracheid diameter and wall thickness. Forestry 70: 47-60.

Mäkinen, H., Saranpää, P., and Linder, S. 2002a. Effect of growth rate on fibre characteristics in Norway spruce (Picea abies (L.) Karst.). Holzforschung 56: 449-460. doi: https://doi.org/10.1515/HF.2002.070 
449

450

451

452

453

454

455

456

457

458

459

460

461

462

463

464

465

466

467

468

469

470

471

472

473

474

Mäkinen, H., Saranpää, P., \& Linder, S. 2002b. Wood-density variation of Norway spruce in relation to nutrient optimization and fibre dimensions. Can. J. For. Res. 32: 185-194. doi: 10.1139/X01-186.

O’Neill, G.A., Aitken, S.N., King, J.N., and Alfaro, R.I. 2002. Geographic variation in resin canal defenses in seedlings from the Sitka spruce $\mathrm{x}$ white spruce introgression zone. Can. J. For. Res. 32: 390-400. doi: 10.1139/X01-206

Reid, R.W., and Watson, J. A. 1966. Sizes, distributions, and numbers of vertical resin ducts in lodgepole pine. Can. J. Bot. 44: 519-525.

Rissanen, A., and Sipi, M. 2002. Puuaineen ja -kuitujen ominaisuudet ojitettujen soiden männyissä. Metsätieteen aikakauskirja no 4/2002: 617-619.

Sjöström, E. 1993. Wood chemistry. Fundamentals and applications. Academic Press, New York. $293 \mathrm{p}$.

Skog, K.E., Wegner, T.H., Bilek, T., and Michler, C.H. 2014. Desirable properties of wood for sustainable development in the twenty-first century. Ann. For. Sci. 72: 671-678. doi:10.1007/s13595-014-0406-0.

Tokareva, E.N., Pranovich, A.V., Fardim, P., Daniel, G., and Holmbom, B. 2007. Analysis of wood tissues by time-of-flight secondary ion mass spectrometry. Holzforschung 61: 647-655. doi: 10.1515/HF.2007.119

Uprichrd, J.M. 1993. Wood extractives. In: Walker, J.C.F. (ed.): Primary wood processing. Principles and practice. Chapman \& Hall, London. p. 56-63.

Willför, S., Hemming, J., Reunanen, M., Eckerman, C., and Holmbom, B. 2003. Lignans and lipophilic extractives in Norway spruce knots and stemwood. Holzforschung 57: 27-36.

Wimmer, R., and Grabner, M. 1997. Effects of climate on vertical resin duct density and radial growth of Norway spruce (Picea abies (L.) Karst.). Trees 11: 271-276.

Zobel, B.J., and Jett, J.B. 1995. Genetics of wood production. Springer-Verlag, Berlin, Germany. $352 \mathrm{p}$. 
475 Zubizarreta Gerendiain, A., Peltola, H., Pulkkinen, P., Jaatinen, R., Pappinen, A., and Kellomäki, S. 476 2007. Differences in growth and wood property traits in cloned Norway spruce (Picea abies).

477 Can. J. For. Res. 37: 2600-2611. doi: 10.1139/X07-220.

478 Zubizarreta Gerendiain, A., Peltola, H., Pulkkinen, P., Jaatinen, R., and Pappinen, A. 2007.

479 Differences in fibre properties in cloned Norway spruce (Picea abies). Can. J. For. Res. 38:

480 1071-1082. doi: $10.1139 / \mathrm{X} 07-220$ 
481 Table 1. Means (X) and standard deviations (SD) of tree and wood properties of the studied Norway spruce 482 clones C43, C308, and C332 according to Zubizarreta Gerendiain et al. (2007).

\begin{tabular}{lccc}
\hline & $\mathrm{C} 43(\mathrm{n}=8)$ & $\mathrm{C} 308(\mathrm{n}=9)$ & $\mathrm{C} 332(\mathrm{n}=10)$ \\
Property & $\mathrm{X} \pm \mathrm{SD}$ & $\mathrm{X} \pm \mathrm{SD}$ & $\mathrm{X} \pm \mathrm{SD}$ \\
\hline Height, $\mathrm{m}$ & $13.4 \pm 0.5$ & $14.0 \pm 0.5$ & $10.8 \pm 0.7$ \\
Diameter (at $1.3 \mathrm{~m}$ height, bark included), $\mathrm{cm}$ & $15.8 \pm 1.5$ & $15.9 \pm 1.3$ & $11.1 \pm 1.1$ \\
Annual rings, number & $22.5 \pm 0.6$ & $22.6 \pm 0.7$ & $21.7 \pm 0.7$ \\
Earlywood width, $\mathrm{mm}$ & $2.7 \pm 0.3$ & $2.9 \pm 0.3$ & $2.0 \pm 0.3$ \\
Latewood width, $\mathrm{mm}$ & $0.7 \pm 0.1$ & $0.7 \pm 0.1$ & $0.5 \pm 0.1$ \\
Width of annual ring, $\mathrm{mm}$ & $3.5 \pm 0.3$ & $3.6 \pm 0.4$ & $2.5 \pm 0.3$ \\
Density of earlywood, $\mathrm{kg} / \mathrm{m}^{3}$ & $352 \pm 7$ & $330 \pm 14$ & $331 \pm 10$ \\
Density of latewood, $\mathrm{kg} / \mathrm{m}^{3}$ & $657 \pm 9$ & $581 \pm 14$ & $581 \pm 17$ \\
Ring density, $\mathrm{kg} / \mathrm{m}^{3}$ & $417 \pm 11$ & $385 \pm 14$ & $380 \pm 14$ \\
\hline
\end{tabular}


Table 2. Means (X) and standard deviations (SD) of measured anatomical characteristics in EW and LW in Norway spruce clones C43, C308, and C332.

\begin{tabular}{|c|c|c|c|c|c|c|c|c|c|}
\hline \multirow[b]{2}{*}{ Anatomical characteristics } & \multicolumn{3}{|c|}{$\mathrm{C} 43$} & \multicolumn{3}{|c|}{ C308 } & \multicolumn{3}{|c|}{ C332 } \\
\hline & $\mathrm{X} \pm \mathrm{SD}$ & $\%$ of $X$ & $\mathrm{CV} \%$ & $\mathrm{X} \pm \mathrm{SD}$ & $\%$ of $X$ & $\mathrm{CV} \%$ & $\mathrm{X} \pm \mathrm{SD}$ & $\%$ of $X$ & $\mathrm{CV} \%$ \\
\hline 2CWT, EW, $\mu \mathrm{m}$ & $4.2 \pm 1.1^{\mathrm{a}}$ & 117.0 & 26.8 & $3.8 \pm 0.8^{b}$ & 106.4 & 19.9 & $2.9 \pm 0.4^{\mathrm{c}}$ & 80.0 & 14.7 \\
\hline $2 \mathrm{CWT}, \mathrm{LW}, \mu \mathrm{m}$ & $9.3 \pm 3.2^{\mathrm{a}}$ & 125.3 & 34.0 & $7.6 \pm 2.3^{b}$ & 102.1 & 30.1 & $5.7 \pm 1.0^{\mathrm{c}}$ & 77.1 & 16.7 \\
\hline Diameter of lumen, $\mathrm{EW}, \mu \mathrm{m}$ & $30.897 .7^{\mathrm{a} . \mathrm{b}}$ & 100.1 & 25.0 & $32.3 \pm 7.5^{\mathrm{a}}$ & 104.6 & 23.2 & $29.5 \pm 5.6^{\mathrm{b}}$ & 95.6 & 18.9 \\
\hline Diameter of lumen, $\mathrm{LW}, \mu \mathrm{m}$ & $11.9 \pm 4.2^{\mathrm{a}}$ & 90.4 & 34.9 & $12.6 \pm 3.9^{\mathrm{a}}$ & 95.4 & 31.0 & $14.8 \pm 2.8^{\mathrm{b}}$ & 112.2 & 18.6 \\
\hline 2CWT:lumen diameter, EW & $0.1 \pm 0.1^{\mathrm{a}}$ & 116.7 & 35.7 & $0.1 \pm 0.0^{\mathrm{b}}$ & 116.7 & 33.3 & $0.1 \pm 0.0^{\mathrm{c}}$ & 83.3 & 20.0 \\
\hline 2CWT:lumen diameter, LW & $0.9 \pm 0.6^{\mathrm{a}}$ & 141.6 & 60.9 & $0.7 \pm 0.4^{\mathrm{b}}$ & 104.6 & 51.5 & $0.4 \pm 0.1^{\mathrm{c}}$ & 52.3 & 25.0 \\
\hline $2 \mathrm{CWT}$ beside resin canals, $\mathrm{EW}, \mu \mathrm{m}$ & $4.1 \pm 0.8^{\mathrm{a}}$ & 112.0 & 20.5 & $4.0 \pm 0.9^{\mathrm{a}}$ & 110.3 & 22.5 & $2.8 \pm 0.4^{\mathrm{b}}$ & 76.1 & 14.5 \\
\hline $2 \mathrm{CWT}$ beside resin canals, $\mathrm{LW}, \mu \mathrm{m}$ & $4.6 \pm 1.2^{\mathrm{a}}$ & 111.7 & 25.2 & $4.5 \pm 0.9^{\mathrm{a}}$ & 110.0 & 19.4 & $3.5 \pm 0.7^{\mathrm{b}}$ & 83.7 & 18.9 \\
\hline Resin canals, EW, no/mm $\mathrm{mm}^{2}$ & $0.4 \pm 0.8^{\mathrm{a}}$ & 91.7 & 170.5 & $0.5 \pm 0.5^{\mathrm{a}}$ & 104.2 & 102.0 & $0.5 \pm 1.0^{\mathrm{a}}$ & 104.2 & 198.0 \\
\hline -of which traumatic, $\%$ & $11.4 \pm 13.6^{\mathrm{a}}$ & 86.4 & 119.3 & $11.9 \pm 12.6^{\mathrm{a}}$ & 90.2 & 105.9 & $16.4 \pm 11.2^{\mathrm{a}}$ & 124.2 & 68.3 \\
\hline Resin canals, $\mathrm{LW}, \mathrm{no} / \mathrm{mm}^{2}$ & $0.7 \pm 1.2^{\mathrm{a}}$ & 85.5 & 174.6 & $0.6 \pm 0.9^{\mathrm{a}}$ & 72.8 & 154.4 & $1.1 \pm 1.5^{\mathrm{b}}$ & 136.6 & 135.3 \\
\hline -of which traumatic, $\%$ & $10.7 \pm 15.3^{\mathrm{a}}$ & 102.9 & 143.0 & $5.4 \pm 12.2^{\mathrm{a}}$ & 51.9 & 225.9 & $15.2 \pm 20.1^{\mathrm{a}}$ & 146.2 & 132.2 \\
\hline Area of normal resin canal, $\mathrm{EW}, \mu \mathrm{m}^{2}$ & $3820 \pm 1715^{\mathrm{a}}$ & 110.1 & 44.9 & $4035 \pm 1701^{\mathrm{a}}$ & 116.3 & 42.2 & $2416 \pm 1376^{\mathrm{b}}$ & 69.7 & 57.0 \\
\hline Area of normal resin canal, $\mathrm{LW}, \mu \mathrm{m}^{2}$ & $3388 \pm 1455^{\mathrm{a}}$ & 111.5 & 42.9 & $3831 \pm 1753^{\mathrm{a}}$ & 126.1 & 45.8 & $2099 \pm 1082^{b}$ & 69.1 & 51.5 \\
\hline Area of traumatic resin canal, $\mathrm{EW}, \mu \mathrm{m}^{2}$ & $4740 \pm 1192^{\mathrm{a}}$ & 133.2 & 25.1 & $3662 \pm 1405^{\mathrm{a}}$ & 102.9 & 38.4 & $2540 \pm 804^{\mathrm{b}}$ & 71.4 & 31.7 \\
\hline Area of traumatic resin canal, $\mathrm{LW}, \mu \mathrm{m}^{2}$ & $3911 \pm 261^{\mathrm{a}}$ & 140.5 & 6.7 & $3921 \pm 2966^{\mathrm{a}}$ & 140.8 & 75.6 & $2168 \pm 912^{\mathrm{b}}$ & 77.9 & 42.1 \\
\hline$\%$ area of resin canals in ring, $\mathrm{EW}$ & $0.3 \pm 0.7^{\mathrm{ab}}$ & 113.8 & 224.2 & $0.3 \pm 0.4^{\mathrm{a}}$ & 110.3 & 112.5 & $0.2 \pm 0.4^{\mathrm{b}}$ & 75.9 & 177.3 \\
\hline$\%$ area of resin canals in ring, $\mathrm{LW}$ & $0.7 \pm 1.1^{\mathrm{a}}$ & 86.6 & 154.9 & $0.9 \pm 1.3^{\mathrm{a}}$ & 111.0 & 140.7 & $0.8 \pm 1.1^{\mathrm{a}}$ & 100.3 & 128.0 \\
\hline Rays, $\mathrm{no} / \mathrm{mm}^{2}$ & $1.9 \pm 1.0^{\mathrm{a}}$ & 83.5 & 50.8 & $1.7 \pm 0.6^{\mathrm{b}}$ & 73.3 & 36.1 & $3.2 \pm 1.7^{\mathrm{c}}$ & 139.1 & 52.7 \\
\hline
\end{tabular}

$\%$ of X: the percentage of the clone means relative to the mean of all three clones. CV\%: coefficient of variation.

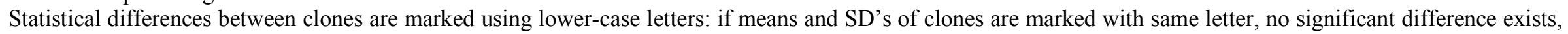
but

if the

letters

are

different,

significant

difference

$(p<0.05)$

exists. 
Table 3. Correlation coefficients between studied anatomical characteristics and earlywood width (EWW), latewood width (LWW), and ring width (RW) by clones.

\begin{tabular}{|c|c|c|c|c|c|c|c|c|c|c|}
\hline \multirow{2}{*}{\multicolumn{2}{|c|}{ Anatomical characteristics }} & \multicolumn{3}{|c|}{ EWW } & \multicolumn{3}{|c|}{ LWW } & \multicolumn{3}{|c|}{ RW } \\
\hline & & C43 & C308 & C332 & C43 & C308 & C332 & C43 & C308 & C3332 \\
\hline \multirow[t]{11}{*}{ Tracheids } & 2CWT, EW & $-0.217^{*}$ & $-0.278^{*}$ & $-0.165^{*}$ & -0.068 & $-0.144 *$ & -0.061 & $-0.213^{*}$ & $-0.270 *$ & $-0.172^{*}$ \\
\hline & 2CWT, LW & $-0.446^{*}$ & $-0.554 *$ & -0.049 & $-0.268 *$ & $-0.263 *$ & 0.100 & $-0.470^{*}$ & $-0.565 *$ & -0.031 \\
\hline & Lumen diameter, EW & -0.096 & $-0.190 *$ & $-0.202 *$ & -0.127 & -0.106 & $-0.256 *$ & -0.117 & $-0.197 *$ & $-0.222 *$ \\
\hline & Lumen diameter, LW & $0.263^{*}$ & $0.252 *$ & -0.094 & $0.310^{*}$ & $0.246^{*}$ & $-0.139 *$ & $0.313^{*}$ & $0.284 *$ & -0.107 \\
\hline & Wall:lumen ratio, EW & -0.079 & -0.033 & 0.076 & 0.023 & 0.065 & 0.131 & -0.066 & -0.017 & 0.088 \\
\hline & Wall:lumen ratio, LW & $-0.476^{*}$ & $-0.491 *$ & 0.018 & $-0.348 *$ & $-0.335 *$ & $0.163 *$ & $-0.516^{*}$ & $-0.523 *$ & 0.040 \\
\hline & Number of samples & 174 & 197 & 210 & 174 & 197 & 210 & 174 & 197 & 210 \\
\hline & 2CWT beside resin canal, EW & $-0.224^{*}$ & $-0.250 *$ & -0.027 & -0.015 & 0.077 & 0.043 & $-0.211^{*}$ & $-0.219 *$ & -0.020 \\
\hline & Number of samples & 107 & 144 & 115 & 107 & 144 & 115 & 107 & 144 & 115 \\
\hline & 2CWT beside resin canal, LW & -0.187 & -0.031 & -0.044 & -0.215 & 0.024 & -0.075 & $-0.288^{*}$ & -0.167 & -0.052 \\
\hline & Number of samples & 82 & 94 & 120 & 82 & 94 & 120 & 82 & 94 & 120 \\
\hline \multirow{10}{*}{$\begin{array}{l}\text { Resin } \\
\text { canals }\end{array}$} & $\mathrm{No} / \mathrm{mm}^{2}, \mathrm{EW}$ & $-0.151^{*}$ & $0.244^{*}$ & 0.025 & $-0.156 *$ & 0.358* & 0.075 & -0.010 & 0.301* & 0.034 \\
\hline & $\mathrm{No} / \mathrm{mm}^{2}, \mathrm{LW}$ & 0.040 & $-0.259 *$ & -0.044 & -0.114 & $-0.151 *$ & -0.083 & 0.079 & $-0.271 *$ & -0.052 \\
\hline & $\%$-area, EW & $-0.262 *$ & $-0.158 *$ & $-0.153^{*}$ & $-0.186 *$ & 0.062 & -0.102 & $-0.283 *$ & -0.132 & $-0.155^{*}$ \\
\hline & $\%$-area, LW & -0.131 & $-0.338^{*}$ & -0.078 & $-0.220 *$ & $-0.224 *$ & $-0.229 *$ & $-0.172 *$ & $-0.359 *$ & -0.104 \\
\hline & $\%$-area, ring & $-0.282 *$ & $-0.376^{*}$ & $-0.279 *$ & $-0.213 *$ & -0.119 & $-0.221^{*}$ & $-0.307^{*}$ & $-0.371 *$ & $-0.287^{*}$ \\
\hline & Number of samples & 174 & 197 & 210 & 174 & 197 & 210 & 174 & 197 & 210 \\
\hline & Mean area, EW & 0.178* & $0.365^{*}$ & $0.246^{*}$ & -0.010 & $0.236^{*}$ & 0.039 & $0.160 *$ & $\mathbf{0 . 3 7 8}^{*}$ & 0.231* \\
\hline & Number of samples & 106 & 143 & 115 & 106 & 143 & 115 & 106 & 143 & 115 \\
\hline & Mean area, LW & -0.031 & $-0.275^{*}$ & 0.041 & 0.056 & -0.049 & -0.017 & -0.015 & $-0.263^{*}$ & 0.036 \\
\hline & Number of samples & 81 & 93 & 120 & 81 & 93 & 120 & 81 & 93 & 120 \\
\hline \multirow[t]{2}{*}{ Rays } & $\mathrm{No} / \mathrm{mm}^{2}$ & $-0.690^{*}$ & $-0.775^{*}$ & $-0.829 *$ & $-0.460 *$ & $-0.396 *$ & $-0.517 *$ & $-0.738 *$ & $-0.796 *$ & $-0.835 *$ \\
\hline & Number of samples & 174 & 197 & 210 & 174 & 197 & 210 & 174 & 197 & 210 \\
\hline
\end{tabular}

* - significant at $0.05 \%$ level. Significant correlations are bolded.

Number of samples is given for above presented correlation(s). 
Table 4. Correlation coefficients between studied anatomical characteristics and earlywood density (EWD), latewood density (LWD), and ring density (RD) by clones.

\begin{tabular}{|c|c|c|c|c|c|c|c|c|c|c|}
\hline \multirow{2}{*}{\multicolumn{2}{|c|}{ Anatomical characteristics }} & \multicolumn{3}{|c|}{ EWD } & \multicolumn{3}{|c|}{ LWD } & \multicolumn{3}{|c|}{$\mathrm{RD}$} \\
\hline & & $\mathrm{C} 43$ & C308 & C332 & $\mathrm{C} 43$ & C308 & C332 & $\mathrm{C} 43$ & C308 & $\mathrm{C} 332$ \\
\hline \multirow[t]{11}{*}{ Tracheids } & 2CWT, EW & $-0.291 *$ & 0.087 & -0.092 & $0.346^{*}$ & $0.264^{*}$ & -0.061 & 0.053 & $0.249 *$ & -0.024 \\
\hline & 2CWT, LW & $-0.302 *$ & -0.033 & $-0.212 *$ & $0.644^{*}$ & $0.612 *$ & $0.166^{*}$ & $0.201 *$ & 0.314 & -0.015 \\
\hline & Lumen diameter, EW & $-0.493 *$ & $-0.519 *$ & $-0.590 *$ & $0.189 *$ & 0.070 & $-0.187^{*}$ & $-0.275^{*}$ & $-0.260 *$ & $-0.414 *$ \\
\hline & Lumen diameter, LW & 0.008 & $-0.275^{*}$ & $-0.339 *$ & $-0.385^{*}$ & $-0.334^{*}$ & $-0.243 *$ & -0.176 & $-0.280 *$ & $-0.277 *$ \\
\hline & Wall:lumen ratio, EW & 0.110 & $0.511 *$ & $0.492 *$ & 0.112 & 0.121 & $0.148^{*}$ & 0.199* & $0.397^{*}$ & $0.364 *$ \\
\hline & Wall:lumen ratio, LW & $-0.184 *$ & 0.127 & 0.122 & $0.590 *$ & $0.532 *$ & $0.285^{*}$ & $0.253^{*}$ & $0.329 *$ & $0.212 *$ \\
\hline & Number of samples & 174 & 197 & 210 & 174 & 197 & 210 & 174 & 197 & 210 \\
\hline & $\begin{array}{l}\text { 2CWT beside resin } \\
\text { canal, EW }\end{array}$ & 0.069 & 0.088 & 0.010 & $0.280^{*}$ & 0.094 & -0.076 & $0.263^{*}$ & $0.206^{*}$ & 0.022 \\
\hline & Number of samples & 107 & 144 & 115 & 107 & 144 & 115 & 107 & 144 & 115 \\
\hline & $\begin{array}{l}\text { 2CWT beside resin } \\
\text { canal, LW }\end{array}$ & -0.114 & -0.031 & -0.082 & $0.341^{*}$ & 0.181 & 0.097 & 0.085 & 0.122 & -0.034 \\
\hline & Number of samples & 82 & 94 & 120 & 82 & 94 & 120 & 82 & 94 & 120 \\
\hline \multirow{10}{*}{$\begin{array}{l}\text { Resin } \\
\text { canals }\end{array}$} & $\mathrm{No} / \mathrm{mm}^{2}, \mathrm{EW}$ & $0.406^{*}$ & $0.215^{*}$ & 0.500* & -0.113 & $-0.267^{*}$ & 0.119 & 0.338* & 0.045 & $0.380 *$ \\
\hline & $\mathrm{No} / \mathrm{mm}^{2}, \mathrm{LW}$ & 0.056 & 0.032 & -0.027 & 0.012 & $0.246^{*}$ & 0.021 & -0.037 & $0.153^{*}$ & -0.032 \\
\hline & $\%$-area, EW & $0.197^{*}$ & 0.098 & $0.142 *$ & 0.048 & 0.010 & 0.006 & $0.323^{*}$ & 0.139 & $0.159 *$ \\
\hline & $\%$-area, LW & -0.003 & 0.058 & $-0.180 *$ & 0.072 & $0.309 *$ & -0.052 & -0.017 & $0.220 *$ & $-0.167 *$ \\
\hline & $\%$-area, ring & $0.170^{*}$ & 0.106 & 0.022 & 0.085 & $0.259 *$ & -0.038 & $0.284 *$ & $0.284 *$ & 0.111 \\
\hline & Number of samples & 174 & 197 & 210 & 174 & 197 & 210 & 174 & 197 & 210 \\
\hline & Mean area, EW & -0.132 & $-0.187^{*}$ & $-0.416^{*}$ & $0.227^{*}$ & 0.038 & $-0.185^{*}$ & 0.089 & -0.062 & $-0.312 *$ \\
\hline & Number of samples & 106 & 143 & 115 & 106 & 143 & 115 & 106 & 143 & 115 \\
\hline & Mean area, LW & -0.160 & 0.010 & $-0.381 *$ & 0.140 & $0.273^{*}$ & -0.137 & -0.083 & $0.237^{*}$ & $-0.314 *$ \\
\hline & Number of samples & 81 & 93 & 120 & 81 & 93 & 120 & 81 & 93 & 120 \\
\hline \multirow[t]{2}{*}{ Rays } & $\mathrm{No} / \mathrm{mm}^{2}$ & 0.143 & $0.227 *$ & $0.224 *$ & $0.166^{*}$ & $0.418^{*}$ & -0.051 & $0.386^{*}$ & 0.458* & $0.520 *$ \\
\hline & Number of samples & 174 & 197 & 210 & 174 & 197 & 210 & 174 & 197 & 210 \\
\hline
\end{tabular}

* - significant at $0.05 \%$ level. Significant correlations are bolded.

Number of samples is given for above presented correlation(s) 


\section{Figure legends}

Fig. 1. Average a) density and b) width for earlywood (EW), latewood (LW), and ring (R) for the Norway spruce clones C43, C308, and C332 by cambial age.

Fig. 2. a) Double thickness of tracheid walls (2CWT), b) tracheid lumen diameter, c) tracheid wall:lumen ratio, and d) double thickness of tracheid walls (2CWT) beside the resin canals of both earlywood (EW) and latewood (LW) for the Norway spruce clones C43, C308, and C332 by cambial age. Breaks in the curves in d): number of resin canals was 0 in few cases.

Fig. 3. a) Number of resin canals $/ \mathrm{mm}^{2}$, b) average area of a resin canal, and c) total area of resin canals of both earlywood (EW) and latewood (LW), and d) number of rays $/ \mathrm{mm}^{2}$ for the Norway spruce clones C43, C308, and C332 by cambial age. (Note: C43 - only one measurement for cambial age of 23 years). 

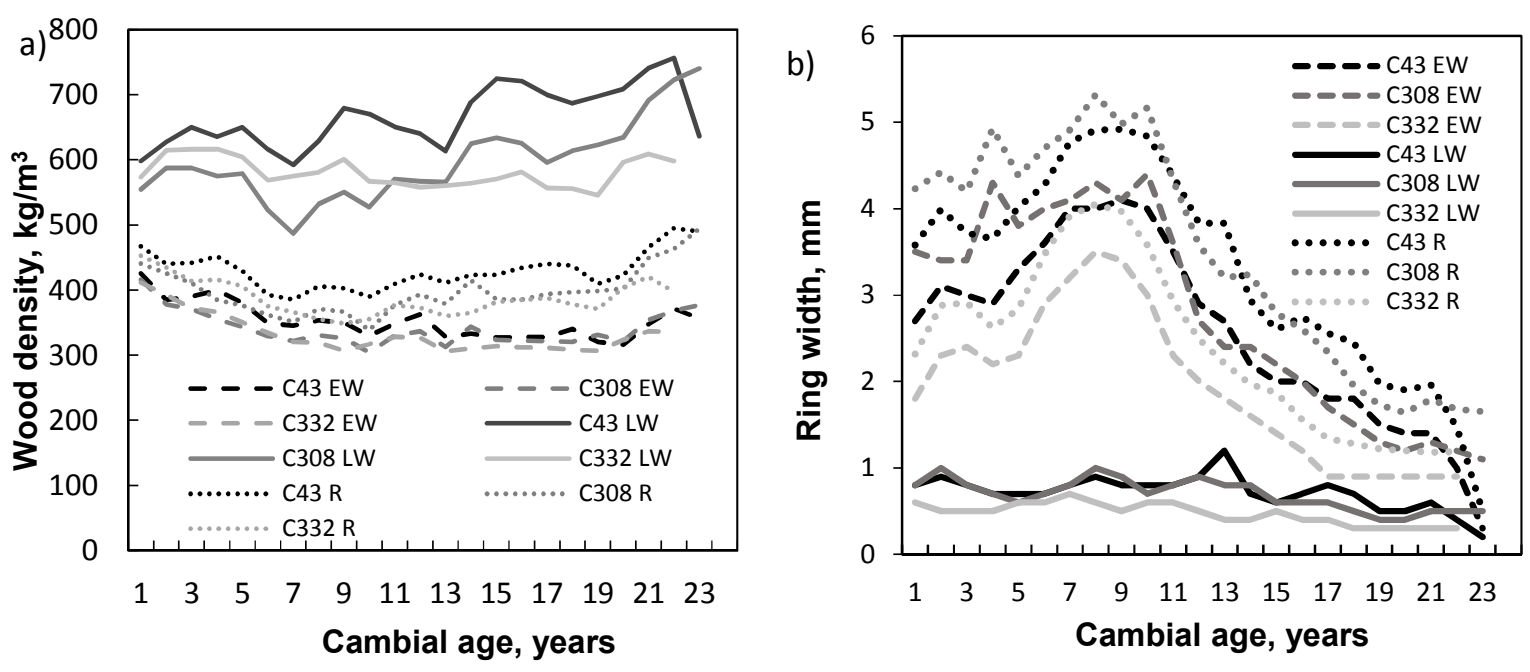

Figure 1. $a, b$ 

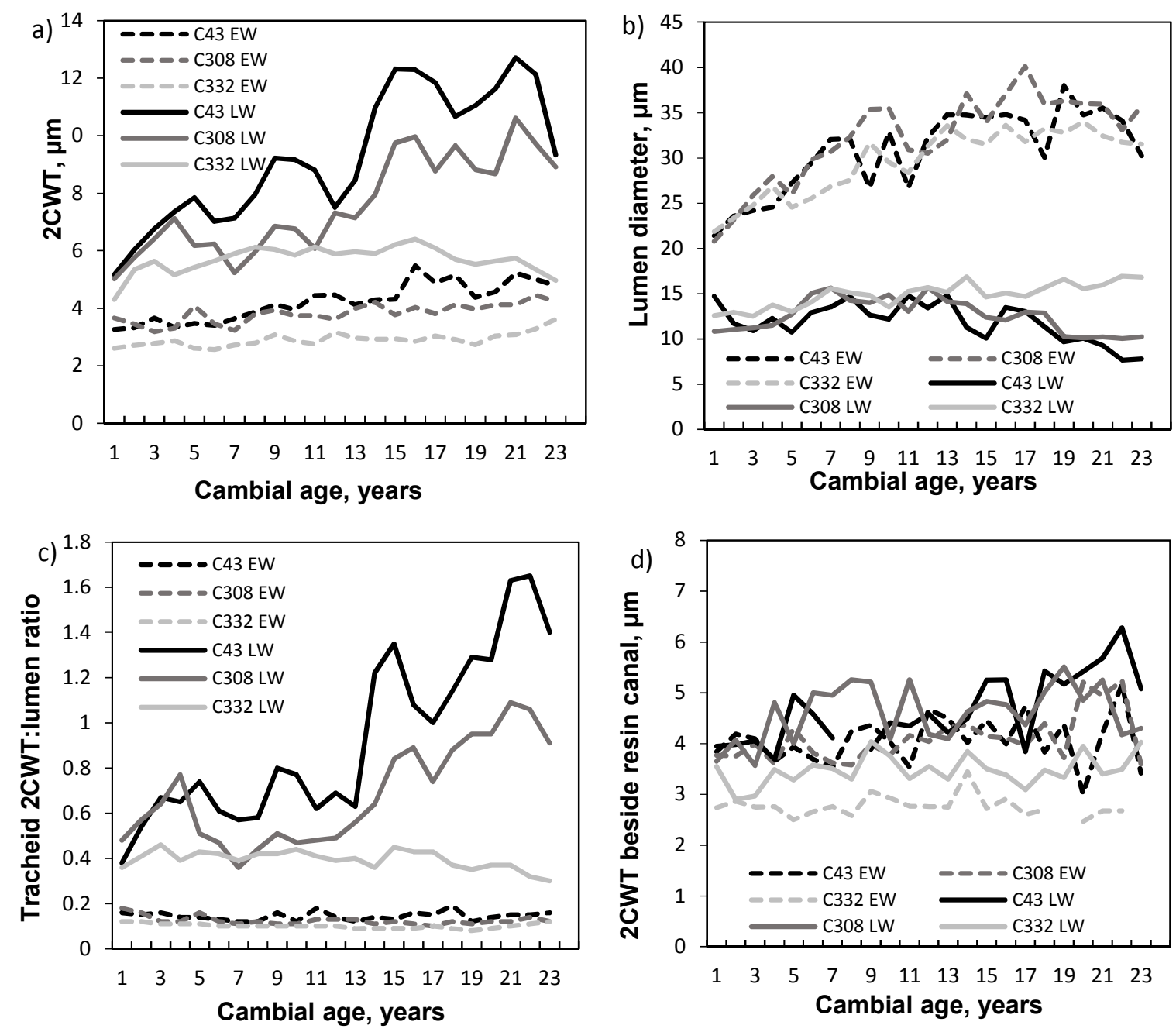

Figure 2. a, b, c and d. 

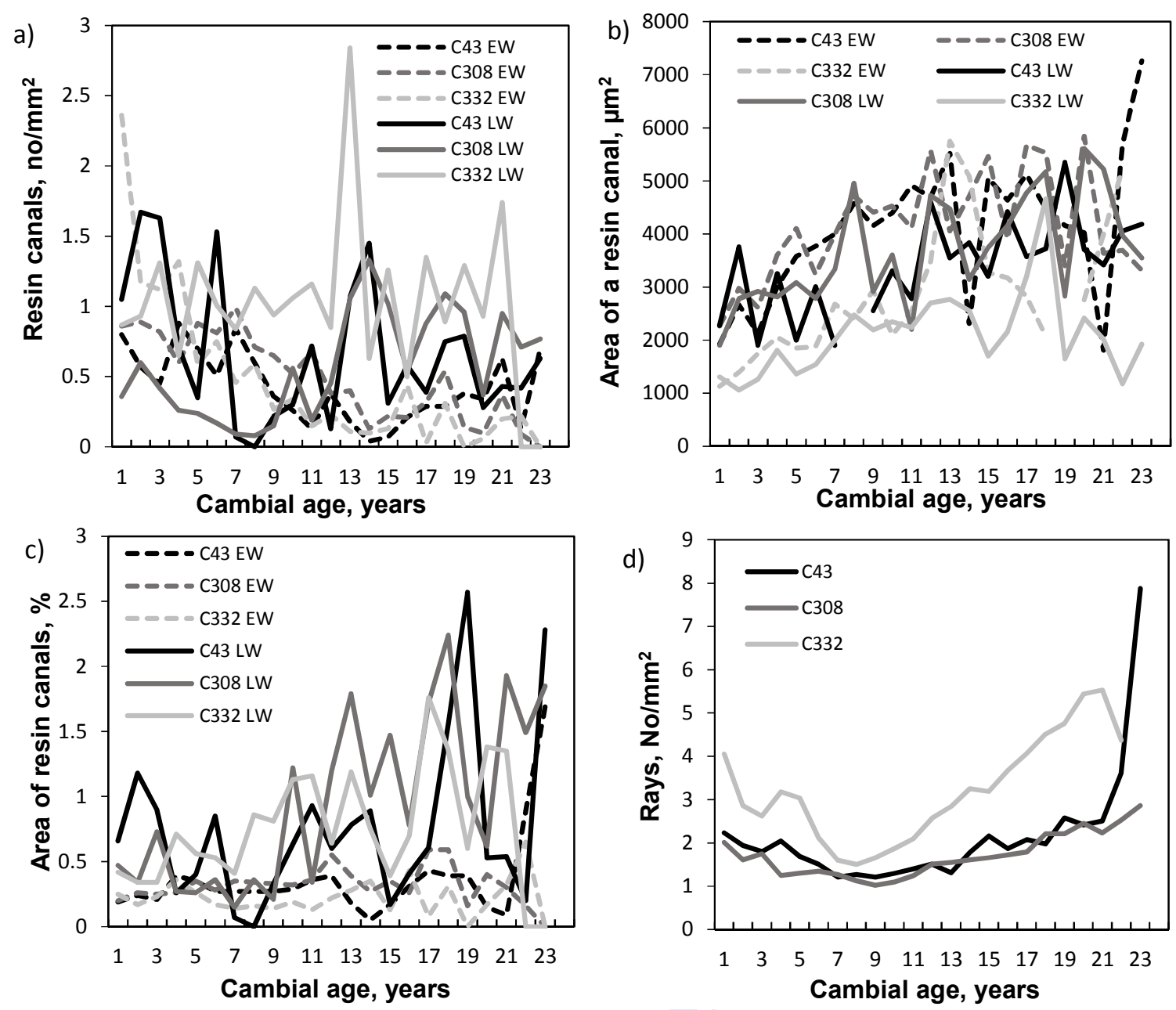

Figure 3. a, b, c and d. 